\title{
Distance Teacher Trainee Perception of Teaching Practice Mentors at the University of Cape Coast, Ghana.
}

\author{
(Mrs.) Clara Akuamoah-Boateng \\ University of Cape Coast, Ghana \\ (Prof.) Josephine Sam-Tagoe \\ University of Cape Coast, Ghana
}

\begin{abstract}
Mentoring as part of teaching practicum has emerged as an effective process through which the professional competencies of trainee-teachers are developed. The practicum experience of teacher training could be pertinent in the context of distance education where the mode of delivery is mainly by print, which do not allow the modelling of acting out ideal examples of teaching. The role of the mentor teacher in the distance education environments of public universities in Ghana therefore becomes critical in quality teacher development. The placement of teacher mentors in school locations for Distance Education trainee teachers during teaching practice helps trainee teachers to model good teaching skills. Trainee teachers are assisted to plan, teach and reflect on their lesson delivery with the view of improving their professional competencies. This paper examines the perception of Distance Education trainee teachers on teacher mentors placed at their school locations during teaching practice. A structured questionnaire was developed to collect data, which was analysed quantitatively using descriptive statistics. The results of the findings based on support for lesson preparation, teaching skills, coaching, teaching experience, and teacher mentors feedback, indicated that more attention could be focused on improving the mentorship of Distance Education trainee teachers at the University of Cape Coast during teaching practice in order to produce quality teachers for the education sector. It was however recommended that strategies to improve and strengthen the mentoring system at the University of Cape Coast, College of Distance Education be planned well to achieve the expected outcomes to the full benefit of trainee teachers.
\end{abstract}

Keywords: Distance education, Teacher-trainees, Techer mentor, Mentoring and Teaching Practicum.

\section{INTRODUCTION}

Throughout the world, a major component of teacher education and the preparation of teachers is Teaching Practice (TP) (Young \& Wright, 2001). In distance learning environments the role of the teacher mentor becomes very critical as trainee teachers' knowledge about teaching is based on theoretical knowledge from their study materials. The critical role played by the teacher mentor for the development of the professional competencies of teacher trainees for the production of quality teachers on Distance Education programmes cannot be overemphasized (Du Plessis 2013; Barry \& King, 1998).

The practicum experience that trainee teachers acquire from teacher mentors during teaching practicum could be pertinent in the Distance Education context where the study materials used, do not allow modelling or acting out ideal teaching methods (Harrison\& Pell, 2006). Mentoring affords trainee teachers the opportunity to refine their teaching methodologies from theoretical ideas about teaching to real teaching practicum. Being mentored, traineeteachers can apply the principles of teaching and learning that they studied during the course 
of study to practical delivery quality lessons under the guidance of a mentor. This is actually the professional development of trainee teachers on any teacher training programme (Ngoepe, 2014).

Mentoring has emerged as an essential and effective process for professional teacher training. The teaching practicum through the mentoring process in Distance Education environments has been studied by many authors such as Ngoepe (2014), Sedibe (2014), Maphalala (2013), Akuamoah-Boateng, Sam-Tagoe \& Brown, (2010), Hudson, (2007) and Smith \& Snoek (1996) from different viewpoints. These research studies in literature points to the impact of teaching practicum experience on the education of teachers in the Distance Education environments of higher institutions. For instance, Smith \& Snoek (1996) reported that trainee teachers from the Netherlands and Israel saw teaching practicum as the most valuable part of their training for the teaching profession. The purpose of this study therefore, is to examine trainee teachers' perception of teacher mentors placed at their school locations during teaching practicum at the College of Distance Education, University of Cape Coast, Ghana.

At the University of Cape Coast, College of Distance Education, teaching practicum provides Distance Education trainee teachers opportunity to apply theoretical knowledge and skills in teaching into practice. The goal of the mentorship is to enable trainee teachers to plan, deliver and evaluate their teaching methods and skills with the cooperation of their mentors. Teaching practicum enables teacher trainees to understand their roles in the larger environment of the teaching profession through professional competencies development. The role of the teacher mentor is therefore crucial in the trainee teachers' growth and development. Mentor teachers as professional educationists are aware of current educational issues, and they are uniquely placed in the school locations of trainee teachers to help them navigate the demands of the teaching practicum. The knowledge, time, energy and experiences of the teacher mentor that is required to make this experience as a valuable one for the trainee teachers. Teacher mentors are very much appreciated by the university collaboration. The university therefore has to ensure that teacher mentors are very clear about their roles and responsibilities in order to effectively support the trainee teachers on teaching practicum at their various school locations.

At the University of Cape Coast, College of Distance Education, during teaching practicum (3credits) the trainee teacher on teaching practicum has two categories of mentors: a professional academic senior member from the University and a professional mentor from the Ghana Education Service who are placed at school locations of trainee teachers for the purpose of the practicum. Inter personal interaction which appears to be a "deficit" in distance learning environments is a key quality value of the Distance Education trainee teachers during their professional development in the mentorship process. This paper proposes that the College of Distance Education, University of Cape Coast could plan and strategize for the maximum utilization of teacher mentors engaged by the College. This is to reinforce trainee teachers' key values for their professional development in the Distance Education context.

\section{THE CONCEPT OF MENTORING}

Mentoring has emerged as an essential and effective process for developing teachers' professional competencies during training. Mentoring is a popular model of teaching practice that enable trainee teachers to enact pedagogical theories using practical realities of the classroom situations. Effective mentoring programmes pair an experienced teacher mentor with a trainee teacher so that the former could provide the latter with regular coaching and feedbacks that are essential for trainee teachers to know areas where they are doing well or where they need improvement (Ngoepe, 2014). 
The term mentoring has been defined in various ways by different authors. Tomlinson (1995) defines mentoring as assisting student- teachers to learn how to teach during field experience. This definition suggests that mentoring is under taken not merely by teachers holding the formal title "mentor" but also by other teachers whose advice and support may be sought or whose teaching and interactions may be witnessed by trainee teachers during the teaching practicum experience. In such teaching practicum exercises, mentors establish a dynamic reciprocal relationship with trainee teachers promoting their career development, reflecting on pedagogical approaches in an effort to improve their professional competencies levels of the mentees (Vonk, 1993).

Mentors, who are sometimes referred to as "supervising teachers" or "cooperating teachers" "lead teachers" or "host teachers" are chosen by the teaching practice units of the teacher education institution (Hudson, 2009). Mavhunga, (2004) opined that Mentoring is sometimes not effective to develop the professional competencies of trainee-teachers and to reflect on their teaching. This is because sometimes mentors are not trained on how to conduct their professional roles and responsibilities during the collaboration for the mentorship.

Historically, a mentor has been used to denote a wise and trusted guide, an adviser or a master teacher. Hobson, Malderez \&Tomlinson (2009) define mentoring as a one-on-one support for a novice or less experience practitioner (mentee) by a more experienced professional (mentor). According to Murray (2001), the action is mentoring if the following aspects could be taken into consideration:

- the mentee and the mentor have confidential discussions;

- the focus is on mentees and mentors reciprocal and personal development;

- they meet regularly;

- they deal with practical issues more than theoretical issues in accordance with mentees interest;

In addition to the above-mentioned structuring, generally, mentoring consists of a contract between the mentee and the mentor which is facilitated by the institution. The institution usually becomes a third party in the collaboration. All these aspects of the mentoring processes are realized in the trainee teachers' practicum processes at the College of Distance Education, University of Cape Coast.

The teacher mentor's roles and responsibilities on the other hand include supporting the mentees' psychological well-being and taking the social aspects of the mentoring process into consideration. Kram, (1983) mentions two basic functions of a mentor: career functions and psychosocial functions. Career function are the aspects of the relationship that primarily enhances career development. While psychosocial function involves the role of modelling, enhancing the sense of competence, clarifying identity and friendship. These basic functions of the mentoring process work well in mentoring relationship in the Distance Education environment. One basic aim of mentoring is that the mentee in the teaching practicum will be able to understand his/her role in the larger scope of the teaching profession and in the extended operational environment of their school locations. This is to enable the mentees to learn how to develop and advance their professional competence levels. It is crucial to recognize that mentoring can have a variety of purposes and goals and can take place at different stages of mentees professional development process.

\section{TEACHING PRACTICUM AT CODE, UCC}

In the distance education environment of University of Cape Coast, College of Distance Education, the purpose of teaching practicum is to provide the trainee teachers with the opportunity to apply their pedagogical knowledge and skills into practicum. Trainee-teachers 
participate in teaching practicum for a minimum period of two semesters (32 weeks) The first 16 weeks is used for on campus teaching practicum where trainee teachers put into practice the theoretical knowledge acquired through their modules with their course facilitators serving as their mentors. They spend the rest of the time for teaching practicum on off- campus at the school locations of their choice. During the off- campus practicum, trainee teachers observe demonstration lessons taught by the host teacher and performs some professional duties assigned to them by the host teacher. As the trainee teachers observe lessons by their host teachers, they write detailed lesson plans, teach lessons putting into practice the accepted pedagogical strategies mutually agreed upon. The teaching practice unit of CoDE provides trainee- teachers with sample lesson plans which, among other things, highlight the essentials professional aspects of the lesson plan, learners' prior knowledge, outcomes, learner activities, steps for lessons delivery, time management and lesson evaluation and closure. Officially, mentees are expected to teach two lessons mostly in English and Mathematics and sometimes other specialized subjects. Evaluation comments are made by the mentors and other supervisors from the University as part of the mentees professional development process and for grading purposes in the course of their studies. The University appoints mentors and other supervisors to the school locations of trainee teachers to mentor and monitor the teaching practicum exercise.

\section{THEORETICAL FRAMEWORK}

At the University of Cape Coast, College of Distance Education, Teaching practicum mentors and supervisors are expected to consider the principles of mentoring an adult learner. The average trainee teacher at CoDE, UCC is about forty years. The distance trainee teachers lead rather typical adult life, by apportioning their time between family, work, and studies. The principles of the adult learning theory andragogy therefore becomes very important in the mentoring processes of trainee teachers as they are predominately adult learners. Andragogy as an adult learning method of teaching and learning thus becomes very critical in the mentoring processes of distance teacher trainees at the College of Distance education, University of Cape Coast.

The theory of andragogy is an adult learning strategy popularized by Malcom Shepherd Knowles (1972). Andragogy recognizes a shift of education from being teacher-led to studentled directed and teacher-guided. Knowles explains that adult learning is driven by five main assumptions: self-concept, life experiences, readiness to learn, orientation to learning, and motivation. A sixth assumption is recognized later in his work.

In 1984, Knowles suggested 4 principles that are applied to adult learning:

1. Adult need to be involved in the planning and evaluation of their instruction.

2. Experience (including mistakes) provide the basis for the learning activities.

3. Adult are mostly interested in teaching subjects that have immediate relevance and impact to their job or personal life.

4. Adult learning is problem- centered rather than content-centered (Kearsley, 2010).

\section{Application of Andragogy in Mentorship at Teaching Practicum}

1. There is the need to explain to mentees the specific professional expectations.

2. Instructions should be task oriented instead of memorization of theories and concepts.

3. Instructions should take into account the wide range of the different backgrounds of mentees.

4. Since adults are self- directed, instructions should allow mentees to discover learning outcomes for themselves without depending on the teacher mentors. However, mentees should be given guidance and help when they make mistakes 
Proper understanding of Knowles's (1972) four principles of Andragogy enables the teacher mentor to better facilitate the mentoring process during the teaching practicum sessions of trainee teachers. The principles could be integrated into the mentorship process for maximum practicum engagement, experience and motivation.

\section{Research Design}

\section{METHODOLOGY}

A quantitative research design was used to examine the perception of Distance Education trainee teachers' perception about the mentoring that they received during their field experience in teaching practicum in the Distance Education environment of the University of Cape Coast.

\section{Sample}

A total population of 200 trainee-teachers on the distance teacher education programme at the College of Distance Education, University of Cape Coast were selected to participate in the study. The random sampling of final year trainee- teachers studying different programmes at the Education Department pursuing diploma (DBE) and post- diploma (PDE) in Education, diploma (DPF) and post diploma(BPF) in Educational Psychology and Foundations of Education constituted the sample. Overall, 50 trainees teachers in each category were chosen for a consistent sample (McMillan \& Schumacher, 2010). All these trainee- teachers study English, Mathematics and other specialized subjects at degree and diploma levels which qualifies them to teach at the basic school level of the Ghana Education Service.

\section{Instrument}

A structured survey questionnaire was developed and used to elicit trainee-teachers' perception of their mentors' assistance or lack of assistance among other things. The instrument was designed based on literature and consisted of a 21 item closed ended questions. The questions were related to trainee- teachers' experience with lesson preparation and delivery, coaching, lesson evaluation, mentors feedback and counselling, and general professional improvement. The questionnaire was developed by the authors of this study based on their experiences as past Coordinators of the Teaching Practicum Unit of the University of Cape Coast, College of Distance Education and with reference to the literature.

\section{Data Collection}

Data was collected using a five- item Likert scale questionnaire (disagree, disagree, neutral, agree, strongly agree) with 21 opinions statements. The questionnaire was piloted in four study centres of one out of the three zones of CoDE, UCC to check for typographical errors and to identify ambiguities. The questionnaire was structured to capture respondents' bio-data and information about their experiences during teaching practicum.

\section{DATA COLLECTION PROCEDURE}

The questionnaires were administered to respondents in their study centres by two research assistants. Respondents were briefed about the purpose of the study and how to respond to questionnaire. They were allowed thirty minutes to complete and return the filled questionnaire to the research assistants. The return rate of the questionnaire was $100 \%$.

\section{Data Analysis}

Descriptive statistics was applied to analyze the data. The categories strongly agreed to agree and strongly disagree to disagree were used in the discussion for easy interpretation. 


\section{RESULTS AND DISCUSSIONS}

The results and discussions are done in line with research questions that guided the study. The results are presented as below.

\section{Trainees Teachers views about Mentors Support with Lesson Plans Preparation.}

\begin{tabular}{|c|c|c|}
\hline Statements & Mean & Std. D \\
\hline My mentor helped me to plan for the lessons I was asked to teach. & 2.26 & .985 \\
\hline $\begin{array}{l}\text { My mentor helped me to write the learning outcomes for the lessons I } \\
\text { taught. }\end{array}$ & 2.10 & .876 \\
\hline $\begin{array}{l}\text { My mentor helped me to decide on the media that I could use to } \\
\text { develop concepts in lessons that I taught. }\end{array}$ & 2.46 & .751 \\
\hline $\begin{array}{l}\text { The mentor identified some teaching skills for me to implement in a } \\
\text { lesson before/during planning. }\end{array}$ & 1.70 & .786 \\
\hline The mentor helped to identify some teaching materials. & 2.31 & .650 \\
\hline Mean of means/SD & 2.16 & .809 \\
\hline
\end{tabular}

As way of achieving the purpose of the study, the trainee teachers were made to rate their views about the teaching practicum in relation to support they get from the teacher mentors for the preparation of their lessons. The results shows that overall, the Distance Education trainees teachers do not get enough support from their teacher mentors for their lessons preparation. The overall results (mean $=2.16, \mathrm{SD}=.809, \mathrm{n}=200$ ) gives evidence to this this revelation. Dwelling on the individual items, the results (mean=2.26, $\mathrm{SD}=.985, \mathrm{n}=200$ ) gives evidence to give evidence to the finding that most of the mentors do not help the trainees teachers to plan for the lessons they are asked to teach. The results (mean=2.10, $\mathrm{SD}=.876$, $\mathrm{n}=200$ ) further shows that teacher mentors do not play major roles in helping the trainee teachers to indicate the expected learning outcomes for the lessons they deliver during the practicum sessions.

In relation to whether the mentors help the trainees teachers to decide on the media that they could use to develop concepts in lessons that they teach, the trainees teachers indicated (mean $=2.46, \mathrm{SD}=.751, \mathrm{n}=200$ ) that the mentors are not active in that regard. In line with the view that the mentors identified some teaching skills for the trainees teachers to implement in the lesson before/during/after lesson delivery. The results (mean=1.70, $\mathrm{SD}=.786, \mathrm{n}=200$ ) from the respondents gave a strong evidence that the majority of the teacher mentors are adamant to that effect and as such do not effectively help in the implementation of the lessons of plans of trainee teachers. On the issue of Identification of some teaching materials, the results was not different in that most of the trainees teachers (mean $=2.31, \mathrm{SD}=.650, \mathrm{n}=200$ ) gave evidence that their mentors are not effective in terms of helping them to identify effective teaching materials for their lesson delivery. 


\section{Trainees Teachers' views on Mentor support for On-Centre Teaching Practice}

Table 2: Means and Standard Deviation Results on Trainees Teachers Views on (On-Centre Teaching Practice)

\begin{tabular}{lcc}
\hline Statements & Mean & Std. D \\
\hline I was taught how to write a good lesson plan. & 2.66 & 1.05 \\
I am aloud to sit in when others are teaching. & 3.48 & 1.76 \\
The facilitator demonstrated some teaching skills during on & 2.96 & 1.51 \\
centre teaching. & 3.00 & 1.36 \\
The facilitator coached me on how to teach good lessons. & 3.31 & .950 \\
The facilitator sat in some of the lessons that I taught. & 3.22 & 1.06 \\
My facilitator encouraged me to use group work during the & & .778 \\
lessons that I taught & & $\mathbf{1 . 2 0}$ \\
My mentor teacher allowed me to use any teaching method that I & 3.09 & $\mathbf{N = 2 0 0}$ \\
thought was useful to develop concepts in lessons I taught. & $\mathbf{3 . 1 0}$ & \\
Mean of means/SD & &
\end{tabular}

Table 2 gives comprehensive results on teacher trainee's views on (on-centre teaching practice). The results from the table gives evidence to suggest that in terms of on-centre teaching practice Teacher Mentors in the respective study centres are working to expectations and doing their best to assist the mentees. This was evident after the majority of the teacher trainees (mean=3.10. $\mathrm{SD}=1.20, \mathrm{n}=200$ ) agreed to that fact they get adequate support from Teacher Mentors at their respective study centers during on- campus teaching practicum. For instance, on the issues of facilitator coaching the trainees teachers on how to deliver good lessons, most of the trainees teachers (mean=3.00, $\mathrm{SD}=1.36, \mathrm{n}=200$ ) confirmed that they received good coaching that enable them to deliver good lessons during the field experience.

The find out whether the Teacher Mentors thoroughly supervise the lessons delivered by Trainee Teachers, the results (mean $=3.48, S D=1.76, n=200$ ) gives evidence that most of the Trainees Teachers are of the view that the facilitators are effective in terms of their supervisory roles. The Trainees Teachers further rated the mentors (mean=3.09, $\mathrm{SD}=.778$, $n=200$ ) on how they are allowed to use any teaching method that they think useful to develop concepts for the lessons they deliver.

\section{Trainees Teachers' Reflections on the Entire Teaching Practicum Experience}

Table 3-Means and Standard Deviation Results on Teacher Trainees views on the Reflections on the Entire Teaching Practicum Experience

\begin{tabular}{lcc}
\hline Statements & Mean & Std. D \\
\hline Teaching practice gave me opportunities to experiment with teaching & 3.26 & 1.85 \\
approaches covered theoretically. & 3.08 & 1.06 \\
I gained a lot of knowledge on how to teach during teaching practice. & 3.96 & .991 \\
I got a lot of insights on how students learn English and Mathematics & 3.70 & 1.36 \\
during teaching practice. & $\mathbf{3 . 5 0}$ & $\mathbf{1 . 3 1}$ \\
All my practice teaching lessons in English and Mathematics are enjoyable. & & $\mathbf{N = 2 0 0}$
\end{tabular}

To give more evidence on the results on Trainee Teachers reflections on the entire teaching practicum experience was solicited. The results shows that teaching practicum have significant impact on the teaching experience of the Trainees Teachers generally. The Trainees Teachers (mean=3.26, $\mathrm{SD}=1.85, \mathrm{n}=200$ ) confirmed that teaching practicum had given them the opportunities to experiment with teaching many approaches covered theoretically. That notwithstanding having the opportunity to experiment with these teaching approaches, the Trainees Teachers also affirmed (mean=3.08, SD=1.06, $n=200$ ) that the teaching practicum had 
helped them gained a lot of Insights about the lesson delivery and the teaching profession as a whole, gaining much insights in the delivery of lessons in English and Mathematics during teaching practicum was also identified by the Trainees Teachers (mean $=3.08, S D=1.06, n=200$ ). With respect to the excitement of teaching lessons in English and Mathematics, the results was not different in that the majority of the Trainees Teachers (mean=3.70, $\mathrm{SD}=1.36, \mathrm{n}=200$ ) indicated that they are excited in delivery lessons in English and Mathematics.

\section{Trainees Teachers views on Mentors Counselling/Feedback.}

Table 4: Means and Standard Deviation Results on the Trainees Teachers Views on Mentors Counselling/Feedback.

\begin{tabular}{lcc}
\hline Statements & Mean & Std. D \\
\hline My mentor provided me with useful feedback after my teaching. & 3.26 & 1.25 \\
$\begin{array}{l}\text { The feedback helped me to improve upon the subsequent lessons } \\
\text { that I taught. }\end{array}$ & 3.18 & 1.76 \\
$\begin{array}{l}\text { My mentor gave me useful feedback on my entire teaching } \\
\text { techniques. }\end{array}$ & 3.06 & 1.11 \\
$\quad$ Mean of means/SD & $\mathbf{3 . 1 6}$ & $\mathbf{1 . 3 7}$ \\
\hline Source: Field Data (2017) & & $\mathbf{N = 2 0 0}$
\end{tabular}

Table 4 gives ample evidence on the Trainee Teachers views of mentors counselling/feedback. The results shows in terms of counselling the Trainees Teachers, give to the mentees. It was revealed that the mentors are up to their task. The results were much evident after the Trainees Teachers' responses produced over all mean of 3.16. In relation to whether the mentor provides useful feedback after my teaching, the results (mean=3.26, $\mathrm{SD}=1.25, \mathrm{n}=200$ ) indicates the mentors are very effective in providing useful feedback for the trainees. The Trainees Techers were consistent in their responses by confirming that the feedback helped them to improve upon the subsequent lessons that they teach (mean=3.18, $\mathrm{SD}=1.76$, $n=200$ ).These results eventually leads to the fact that the mentors gave them useful feedback on the trainees' entire teaching techniques (mean=3.06, SD=1.11, $\mathrm{n}=200$ ).

\section{Trainees Teachers Views about Teacher Education by Distance Education}

Table 5: Means and Standard Deviation Results on the Trainees view about Teacher Education by Distance Education.

\begin{tabular}{lcc}
\hline Statements & Mean & Std. D \\
\hline $\begin{array}{l}\text { The mathematics and English teaching methods covered in the course } \\
\text { prepared me well to teach the subject during teaching practice. }\end{array}$ & 3.33 & 1.15 \\
$\begin{array}{l}\text { The study material covered enough content that helped me to teach } \\
\text { well during teaching practice. }\end{array}$ & 3.51 & 1.00 \\
Mean of means/SD & $\mathbf{3 . 4 2}$ & $\mathbf{1 . 0 7}$ \\
\hline Source: Field Data (2017) & $\mathbf{N = 2 0 0}$
\end{tabular}

Results on the Views about Trainee Teachers Views about teacher education by distance education are presented in Table 5. The results shows that the Trainees Teachers have the conviction that distance education programme is very comprehensive in that Mathematics and English teaching methods covered in the course materials prepared them well to deliver good lessons in the subjects during teaching the practicum experience. (mean=3.33, $S D=1.15$, $\mathrm{n}=200$ ). The results further shows that study materials covered enough content that helped them to teach well during teaching practicum sessions (mean=3.15, $\mathrm{SD}=1.00, \mathrm{n}=200$ ). 


\section{Views of the Trainees on the Teaching Subjects}

Table 6: Means and Standard Deviation Results on the Trainees view on the Teaching Subjects

\begin{tabular}{lcc}
\hline Statements & Mean & Std. D \\
\hline English and Mathematics are the most difficult subjects to teach. & 1.26 & .885 \\
Mathematics and English involves a lot of preparation for teaching & 3.48 & .976 \\
The Mathematics content in the classes that I taught were difficult. & 2.12 & 1.23 \\
It is essential that mathematics be taught well in the foundation, & 3.45 & 1.52 \\
intermediate and senior phase. & & \\
After qualifying as a teacher, I will prefer to teach English and & 3.61 & 1.26 \\
Mathematics to other subjects. & $\mathbf{2 . 5 4}$ & $\mathbf{1 . 1 7}$ \\
\hline Mean of means/SD & & $\mathbf{N = 2 0 0}$
\end{tabular}

On the issue of teaching subjects the Trainees Teachers shared varied views. For example Trainees Teachers responses (mean $=1.26, \mathrm{SD}=.885, \mathrm{n}=200$ ) shows that English and Mathematics are difficult subjects to teach. This was in line with the fact that mathematics content in the classes that they taught were difficult (mean=2.12, $\mathrm{SD}=1.23, \mathrm{n}=200$ ). However, they further indicated that Mathematics and English involves a lot of preparation for teaching (mean=3.48, SD=.976, $\mathrm{n}=200$ ).

The Trainees Teachers gave a strong evidence to believe that it is essential that mathematics be taught well in the foundation, intermediate and senior phases of the Distance Education programme (mean=3.45, SD=1.52, $\mathrm{n}=200$ ). Amidst all these responses, the Trainees Teachers confirmed to teach English and Mathematics when they complete their course (mean=3.61, $\mathrm{SD}=1.26, \mathrm{n}=200$ ).

\section{CONCLUSION}

Mentoring is regarded as a central strategy in the professional development of trainee teachers at UCC, CoDE. It plays an important role in initiating trainee teachers to the teaching profession. Although the concept of mentorship is generally understood by all mentors currently engaged by CoDE, UCC could enhance the roles and responsibilities of mentors in supporting trainee teachers by offering ongoing workshops and keeping frequent contacts with mentors at their school locations to support their work. Mentors motivation is a surest way to increase commitment to execute the responsibilities very well for the best expected outcomes.

\section{RECOMMENDATIONS}

There is the need for UCC, CoDE to invest more time and resources to develop a pool of mentors that will support trainee teachers at their school locations. CoDE also needs to appreciate the fact that becoming a good mentor takes time, as result, ongoing workshops should be organized for mentors regularly with the view to improving their skills. In recognition of the roles and responsibilities mentors assumed, they should be motivated to contribute positively towards the professional development of the trainee teachers on the distance mode. Motivation may be in the form of certificates of recognition, end of year recognition functions. UCC, CoDE should ensure that teacher trainees have a suitable mentor at their school locations.

\section{References}

Akuamoah-Boateng, C., Sam-Tagoe, J., \& Brown, P. (2010). Issues, prospects and challenges in practicum Organisation for teachers on the distance mode of education: the case of University of Cape Coast. In Teacher Education Conference and Proceedings (July, 2010) (pp. 97-106). 
Barry, K., \& King, L. (1998). Beginning teaching and beyond. Cengage Learning.

Du Plessis, E. (2013). Mentorship challenges in the teaching practice of distance learning students. The Independent Journal of Teaching and Learning, 8(1), 29-43.

Harrison, J., Dymoke, S., \& Pell, T. (2006). Mentoring beginning teachers in secondary schools: An analysis of practice. Teaching and teacher education, 22(8), 1055-1067.

Hobson, A. J., Ashby, P., Malderez, A., \& Tomlinson, P. D. (2009). Mentoring beginning teachers: What we know and what we don't. Teaching and teacher education, 25(1), 207-216

Hudson, P. B. (2009). How can preservice teachers be measured against advocated professional teaching standards? Australian Journal of Teacher Education, 34(5), 65-73.

Kearsley, G. (2010). Andragogy (M. Knowles). The theory into practice database.

Knowles, M. S., Holton, E., \& Swanson, R. (1972). Andragogy. NETCHE.

Maphalala, M. C. (2013). Understanding the role of mentor teachers during teaching practice session. International Journal of Educational Sciences, 5(2), 123-130.

Mavhunga, P. J. (2004). A study of the role of teacher-mentors in the supervision of secondary school student teachers on teaching practice attachment. Zimbabwe Journal of Educational Research, 16(1), 53-69.

McMillan, J. H., \& Schumacher, S. (2010). Research in education. Evidence-based research.

McMillan, J. H., \& Schumacher, S. (2010). Research in Education: Evidence-Based Inquiry, My Education Lab Series. Pearson.

Murray, M. (2001). Beyond the Myths and Magic of Mentoring: How to Facilitate an Effective Mentoring Process, Revised Edition.

Ngoepe, M. G. (2014). Examining student teachers' perceptions on mentoring during field experiences in distance learning: A pilot study. Journal of Social Sciences, 40(1), 41-49.

Parker, V. A., \& Kram, K. E. (1993). Women mentoring women: Creating conditions for connection. Business Horizons, 36(2), 42-52.

Sedibe, M. (2014). Exploring student teachers' perceptions on mentoring during school experience at high schools in Gauteng Province, South Africa. Journal of Educational and Social Research, 4(3), 197.

Smith, K. (1998) School Models of Teacher Development, 2 (1), 105-22.

Tomlinson, P. (1995). Understanding mentoring. Reflective strategies for school-based teacher preparation. Buckingham, Open University press.

Vonk, J. H. C. (1993). Mentoring Beginning Teachers: Development of a Knowledge Base for Mentors.

Young, Y.; Wright, V. (2001), Mentoring: The Components for Success: Journal of Instructional Psychology. 